\title{
Women Government Officials in The Circle of Corruption
}

\author{
Amalia Syauket \\ \{amalia.syauket@dsn.ubharajaya.ac.id\} \\ University of Bhayangkara, Jakarta Raya
}

\begin{abstract}
This democratic era has opened up enormous opportunities for men and women to play an active role in public policy to occupy strategic positions - administrators of government as regional heads. However, as government administrators, it turns out that women are as involved as men in corruption. The fact or that influences the corrupt behavior of women administrators is the power they have. With the power it has, it means the ability to act, driven by greed. Another factor is the pragmatic-hedonistic lifestyle. The research question is how deep are women administrators involved in corruption. Using qualitative research methods with a phenomenological type. Using secondary data sources in the form of literature studies. This study takes an example of two intellectual actors in local government where these women are public officials.
\end{abstract}

Keywords : Government Officials, Women, and Corruption.

\section{Introduction}

Politics and power as born and bred from democracy has positioned men and women in the same level. Moreover, political and power constellation doesn't segregate gender nowadays. This is where the challenge occurs as a person of politics and power, theirintegrity is at stake, regardless of the gender. It's not about you being a good looking men or woman, a well known public figure or not, also not about somebody who can say wise words from their mouth like an angel. The line between masculine and feminine zone is not that clear anymore.

Post era of reformation, the need of involving women in politics in terms of quantity and quality rose due to the statistics that the number of women is relatively larger than men. State's political decision then regulates the minimal amount of 30 percent of women in the house of representative. The bigger the better, in order to accommodate their 'special' needs, resulted in political decisions regarding women's public needs.

When the modernization of democracy was opened, and lots of women entered this 'masculinity' zone of politics in Indonesia, the society has high hopes for them. Feminine side of women was expected to be a 'game changer.' Intuitive, caring, tender, and aes thetic, with those traits, at least women can enrich positive dynamics in the political world.

However, the reality in public domain is not as good as their subconscious mind. The rise of women government officials in the center of corruption cases in Indonesia has shocked the society, who still has high hopes to these women in politics. They are not better than the men. The feminine-masculine line slowly vanish in public eyes when those 'beautiful yet famous' women announced as a suspected corruptor. Sometimes their husbands are involved, sometimes it's thems elves. Corruptor doesn't differentiate gender, anyone can behave that way. Corruption happens notbecause of he or she, but because the abuse of power and authority to get pers onal advantage, by using their family, friends, relatives, and others. As an addition, corruption happens due to the weak law enforcement low in come of the state apparatus, the habit of gratification, permis siveculture (no 
social control), and the lack of religion and ethic values. The act of corruption doesn't differentiate gender, but the impact of corruption has a dimension of gender.

\section{ANALYSIS AND DISCUSSION}

Corruption is a violating behavior in a formal obligation of a public role due to individual interest (personal, family, close groups) in formof money or status; or rules violation by influencing other party based on personal interest. It consists of several actions like bribe (bribing to influence judgments or decisions of ones in a public trust position);

nepotism (the act of patronizing based on personal relation instead of professional competence criteria); gaining something by corrupting (illegally taking over public resources for their personal interest). [1]

Politics is not only about concept, but also person, process, relation, institution, and procedure making wise public decisions. Every political matter can be categorized as political action. Politics in a nation concerning is sues such as authority, decision making, public policy, and allocation or distribution.[2]

Other definition, corruption derived from Latin language corrumpere, meaning to misuse, distort, destroy, brake. What is misused? Authority or power. Distort from what? From regulation, norms, or morality. What is destroyed and broken? Trust is destroyed and broken. All of this means corruption is a very negative word because it refers to a destructive and damaging behavior.[3]

Corruption is not just a systemic and bureaucratic mistake, it can be a group crime as well, if ones was doing it for the sake of their group interest, i.e. political party. Isn't it the structure of parties needs a lot of money to win the election? Fromthe other side, it is a common thing when parties defend the ir members who involved in corruption as long as they still considered as highly respected members of the party.[4] The reas ons of corruption in Indonesia mainly regarding s mall salary, poor economic condition, mental crisis of the officials, certain adminis tration and management condition resulted in a circumvent procedure. Reas ons mentioned above can be broaden by a desire to buy certain things or good that can increase their perso nal or family prestige or status such as cars, houses, villas, etc. The money, of course, came from act of corruption, and buying such things is a way to blur the result of corruption. To fulfill such economic and consumptive impulse, also with their wives and families keep pushing, this forces them to take money from the state by violating the law.[5]

Those facts raise a question, what is the relation between women and corruption? 30 percent of women quota policy doesn't make them politically fluent. Research about the relation between women and politics started in 1999 by World Bank. It was conducted by David Dollar, Raymond Fishman, and Roberta Gatti (1999)[6], where they found a positive correlation between the amount of women in the legislative and public institution and the level of corruption in a country.

This study then resulted in a theory that the increase amount of women in the legis lative and public institution will decrease the level of corruption.

The recommendation of the study was: women is considered as a group who can create an honest and clean government, thus, the involvement of women in a public world should be increased. Of this recommendation, since 1998 lots of nation has encouraged women to be involved in a public world with the goal was to create an honest aspect in public activities. This condition was not only for legislative institution, but also public world in general. It is believed that the more women involved in a public world, the lower the practice of corruption.

But this is completely the opposite of reality. Phenomena of women politician has been linked to is sues of their corrupt behavior, women celebrity as candidate for people's representative, or family members of the 
elites in political parties as candidates for people's representative (political dynasty). Stigma of women entered into politics closely related to corruption issue, fame, nepotism, not because of the skills or capabilities they posses. The example of the act of corruption by Angelina Sondakh, Miranda Goeltom, Wa Ode Nurhayati, and Neneng Sri Wahyuni, becomes an image as if women are prone to corruption.

The list of so many women involved in corruption case showed that emancipation has been applied in all areas including corruption. The phenomenon of women in the circle of corruption is a relatively new indication in Indonesia. Women with political authority tend to do more corruption compared to the ones with no authority whatsoever. Women or men, when they have discretion and lack of supervision, they do abuse of power.

Phenomenon of women in the circle of corruption is a relatively new indication in Indonesia. The stres sing is not on whether it is accidental or intentional, but how we perceive social change in terms of gen der as the context and feminism related to those money scandals. The Anti-domestication Euphoria of social political freedom widely open post reformation era had positive impact to the empowerment of women acceleration in public sector. After being domesticated for a while by bias gender policies, women in Indonesia slowly found their 'true self.' Many movements from the feminist demanding in the equality opportunity to access social resources, economical-political like men do, started to be affirmed a lot by stakeholders and decision makers in this country.[7]

\section{a. Government Officials Women as the actor of corruption}

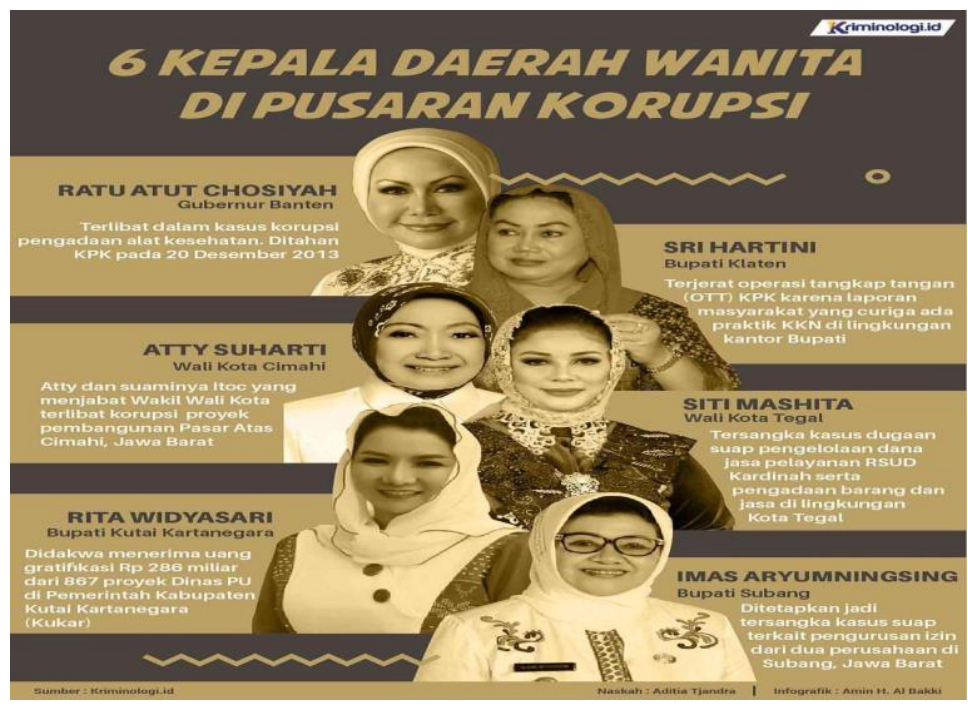

Source: Http://picdeer.com/kriminologi.id

That info graphic shows there are six Head of The Region in the circle of corruption, they are: Ratu Atut Chosiyah as the Governor of Banten, Sri Hartini as the Regent of Klaten, Atty Suharti as the Major of Cimahi, Siti Mashita as the Major of Tegal, Rita Widyasari as the Regent of Kutai Kartanegara, and Imas Aryumningsing as the Regent of Subang whereas all of them been trusted by the society to rule the government in their own areas. Women as corruptor, explored in two things simultaneously: the criminal act of corruption and defamation regarding their glamorous lifestyle.

Women as a corruptor is the woman with political power, discretion, lack of supervision, those are the ones doing abuse of power. The increasing number of women involved in the act of corruption is the consequence of their increasing number of women in the government, legislative, judicative, and private sector. 
Such a shame that their skills in competing with men followed with their competing in terms of doing corruption.

These women government administrators enter into the circle of corruption because of the opportunity, the exis tence of an appropriate target, namely targets that can be corrupted and strengthened with the ability to act as government adminis trators. while the moral drive to commit corruption is because it obeys a pragmatic attitude and the strong ideology of materialism so that it always pursues wealth piling up as high as a mountain so that it does not know haram-halal

\section{b. Why most women involved in politics dragged into the circle of corruption?}

The next discussion concerns two female government adminis trators who are phenomenal with the amount of statemoney that has been successfully corrupted and the behavior of hedonist-materialis $m$ as well as their beauty, namely Ratu Atut Chosiyah - the Governor of Banten and Rita Widyasari - the Regent of Kutai Kertanegara, as examples of cases of women adminis trators in the circle of corruption.

Hedonismand the socialite lifestyle were often mentioned as the cause. It was revealed by the ex Law Bureau of Commission of Corruption Eradication (KPK), Chatarina Girsang, when she was a speaker at a discussion show "Women Against Corruption", at Indonesian Corruption Watch office in Kalibata, South Jakarta (April 27 $\left.{ }^{\text {th }}, 2015\right)$. "Hedonism can't be erased from women's motive to do corruption", she said.

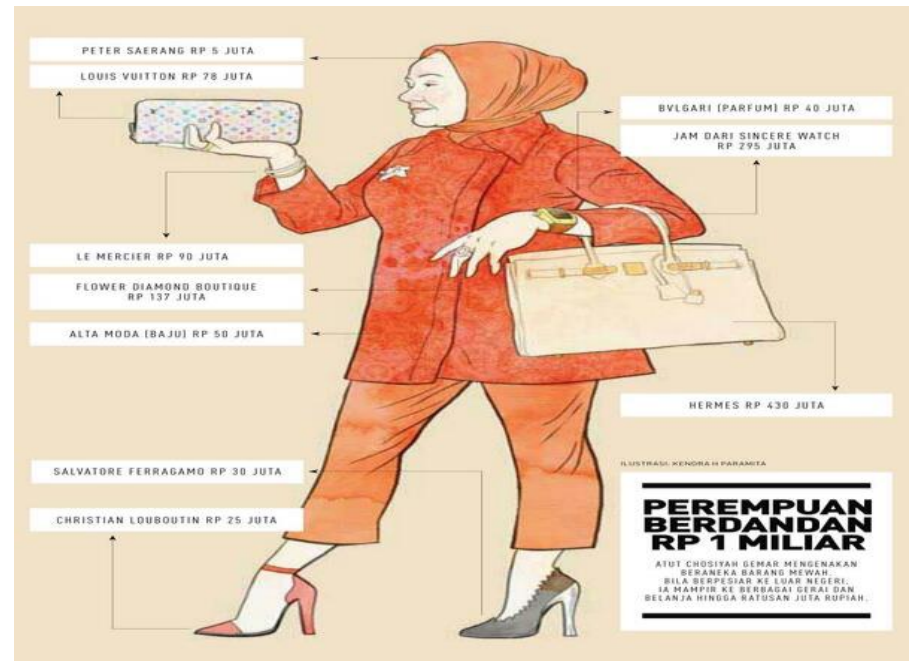

Source: Http://kembiri.blogs pot.com/2013/11/pic-inilah-ratu-atut-chosiyah-kim.html 


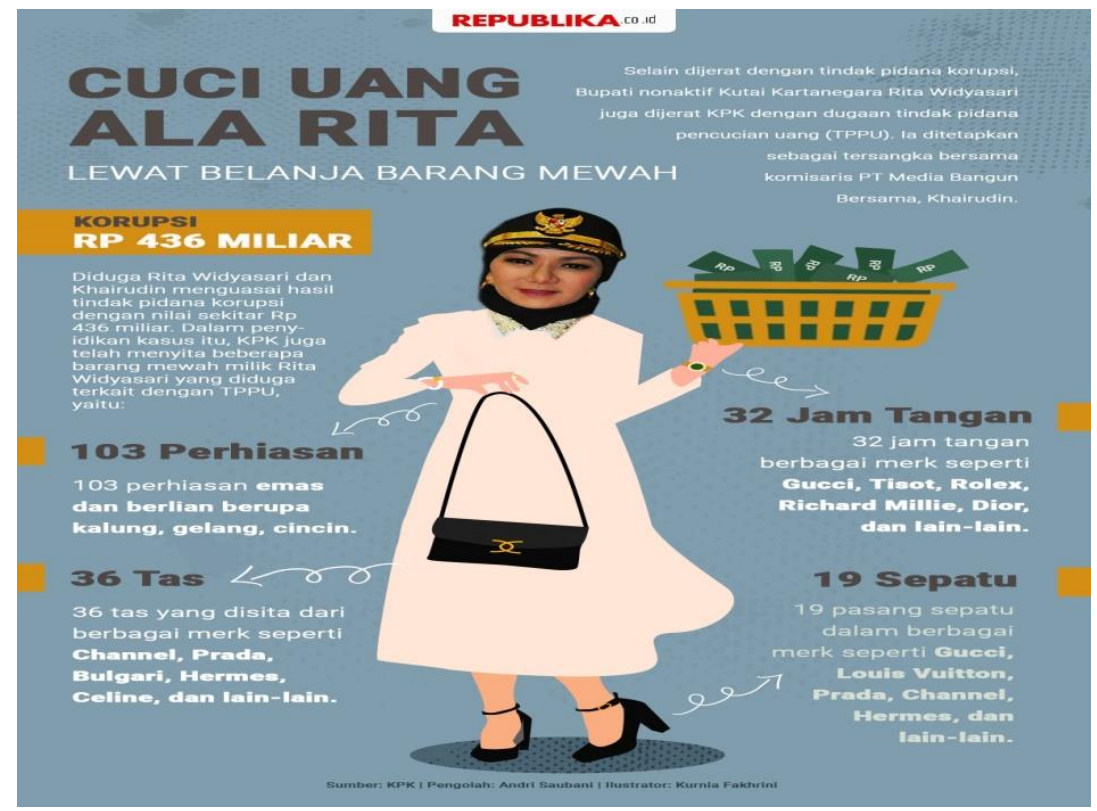

https://republika.co.id/berita/p3ffag318/cuci-uang-ala-bupati-rita-widyasari

Pictures abovetaken fromseveral medias which uploaded illustration of Ratu Atut as women getting dressed with the worth of 1 billion rupiah. So is Rita Widyasari, Regent of Kutai Kertanegara. Those two pictures specified the prices of goods worn by Ratu Atut and Rita from head to toe.

Hedonistic lifestyle like the celebrities has triggered this mothers and wives to fulfill their desires. Expensive socialite lifes tyle, travelling abroad, eating at fancy restaurants, shopping expensive goods and make ups, are habits of the wives of officials or rich mothers nowadays. No matter how much their husband is making, it will never be enough to satisfy their desires. That condition will make their hus band or themselves to gain more money instantly even if it's against the law. Corruption, bribe broker, bribe taker, or kickback as the option.[8] Besides hedonism, white collar corruption, derived from greediness factor, it doesn't neces sarily greed in money, but also in power or authority. Women femininity, mother's instinct to nurture and protect, cannotbe a guarantee to overpower another human's basic instinct: greed. So, in terms of corruption, there is no feminine or masculine. Men and women are the same.[9]

Crime of corruption with women as the suspect in Indonesia started to be worrying. In the recent moments, the number of corruption case involving women has increased. The 'rich and famous' lifestyle made these women crossed the line. Lavish lifestyle and habits of using branded goods encouraged the act of corruption.

\section{Conclusion}

In the circle of corruption, women can act as victims of corrupt behavior, there are also those who act as brokers or intermediaries forbribery and cooperate with their husbands to commit corruption or save the proceeds of corruption. In fact, they themselves become intellectual actors or corruptors in the sense that women are government officials who commit corruption. This shows the dark side of women in their status as dialectical objects, namely dynamic subjects with unexpected circumstances. 


\section{Reference}

[1] B. H. Priyono, Korupsi: Melacak Arti, Menyimak Implikasi. Jakarta: Gramedia Pustaka Utama, 2018.

[2] F. Hanum, Kajian dan Dinamika Gender. Malang: Intrans Publishing, 2018.

[3] A. G. P. Abidin, Zainal. Siswadi, Psikologi Korupsi. Bandung: PT Remaja Rosdakarya, 2015.

[4] A. Sudiarja, Percakapan Politik. Jakarta: Penerbit Buku Kompas, 2018.

[5] Burhanuddin Has an, "Korupsi, Ciri, Sebab, Pemberantasan Dan Kendala-kendalanya," Pemerintahan, vol. IX, no. 17, 2014.

[6] D. R. F. R. G. Dollar, "Are women really the 'fairer' sex? Corruption and women in government," $J$. Econ. Behav. Organ., vol. 46, no. 4, pp. 423-429, 2001, doi: 10.1016/S0167-2681(01)00169-X.

[7] Dewi Sekar Kenconodan Bhakti Wisnu Wardhana, "PEREMPUAN DAN KORUPSI PADA RANAH PUBLIK (Ditinjau dari Gaya Kepemimpinan, Politik, Agama, Psikologi dan Budaya Ketimuran)," J. Ilmu Polit., vol. 3, no. 2, pp. 84-97, 2013, doi: 2502-776x.

[8] Riri Yanti Zahrul, "Keterpurukan Perempuan Dalam Kasus Korupsi Hiasi Media Massa," Academia.edu2019.

http://www.academia.edu/10911482/Keterpurukan_perempuan_dalam_kasus_korupsi_hiasi_ media_massa,.

[9] S. Yuliani, "Perempuan,Politik dan Korupsi," fisip.uns.ac.id, 2019. http://sriyuliani.staff.fisip.uns.ac.id/opini/perempuan-politik-dan-korupsi/ (Accessed February 2nd, 2019) (accessed Feb. 02, 2019). 